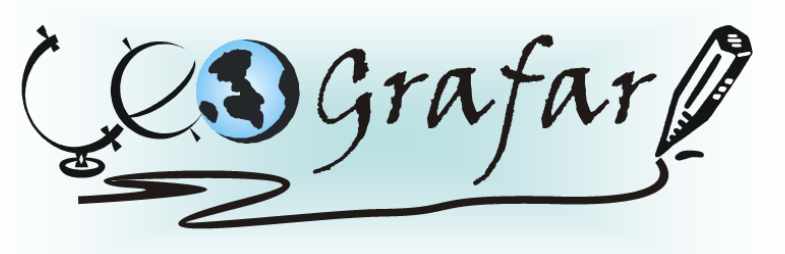

Revista Eletrônica do Programa de Pós-Graduação em Geografia - UFPR

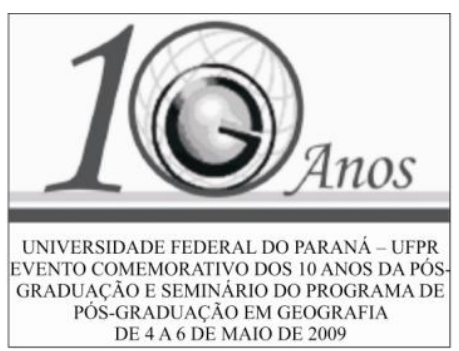

\title{
BAIRRO DE SANTA FELICIDADE - CURITIBA, A INFLUÊNCIA DO TURISMO NA TRANSFORMAÇÃO DO ESPAÇO URBANO LOCAL.
}

\author{
MARCELO CALDART ${ }^{1}$ \\ MIGUEL BAHL ${ }^{2}$

\section{LINHA DE PESQUISA: PRODUÇÃO E TRANSFORMAÇÃO DO ESPAÇO URBANO REGIONAL.}

Este trabalho visa analisar a influência que exerce as milhares de pessoas, que freqüentam semanalmente o bairro de Santa Felicidade em Curitiba, na população e paisagem local, realizando o chamado turismo gastronômico. São turistas que vem de diversas localidades do país e de fora deste. Buscará interpretar o que reflete na vida dos moradores esse fluxo turístico, como se dá a circulação da renda na região, qual a reflexão dos moradores e de técnicos especializados em geografia e turismo, e a influência na formação da paisagem local. O trabalho se dividirá, na primeira parte, no levantamento teórico que se insere o bairro da pesquisa, a estrutura interna da Geografia Urbana e seus conceitos metodológicos. $\mathrm{Na}$ segunda parte as relações históricas de Santa Felicidade com o estabelecido núcleo turístico gastronômico. A circulação da renda devido ao turismo (efeito multiplicador) e a transformação da paisagem local e ambiental pela cultura turística de origem predominantemente italiana. A terceira parte se fará a pesquisa que se fundamentará na interpretação de mapas mentais buscados com alunos dos Colégios da região, com a aplicação do triângulo metodológico de Anne Whyte em moradores do bairro e questionários aplicados aos técnicos da área de Geografia e Turismo. A última parte se fará uma interpretação das pesquisas, identificando como o turismo participa na formação da geografia urbana do bairro. Os resultados poderão determinar uma tendência de médio e longo prazos no que se refere a

\footnotetext{
${ }^{1}$ marcelocal@seed.pr.gov.br

${ }^{2}$ Professor orientador
} 
Revista Geografar

Resumos do VII Seminário Interno de Pós-Graduação em Geografia

Curitiba, 2009 www.ser.ufpr.br/geografar

ISSN: 1981-089X

continuidade desta tipologia turística, também poderá auxiliar em novas pesquisas, em investimentos e orientações paisagísticas e urbanas.

Palavras-chave: Santa Felicidade; gastronomia; transformação. 